\title{
Physicians, Medical Associations and Death Penalty
}

Two distinguished fellows of the American Psychiatric Association (APA), Abraham Halpern and Alfred Freedman, have written [Psychiatric News, Jan 7, 2000, p. 24] about a very important accomplishment of a senior group of the APA, the Lifers. In June 1998, in a near-unanimous vote, it passed a resolution calling upon APA to "urge all federal and state jurisdictions to abolish the death penalty and commute the sentences of more than 3,200 death-row inmates to life imprisonment without parole'. They recalled the APA Board of Trustees' denunciation of the death penalty in 1969 ('the best available scientific and expert opinion holds it be anachronistic, brutalizing, ineffective, and contrary to progress in penology and forensic psychiatry'). Halpern and Freedman, however, remind us that motions calling for a moratorium on the death penalty in the US or outright abolition of capital punishment have been rejected by the APA, American College of Physicians, American Academy of Psychiatry and the Law, and the American Medical Association. I wonder whether anything can be done to support this small group of American physicians. American medical associations have relatively large international memberships. For instance, I am a fellow of the APA, and I feel embarrassed to be a member of an association which fails to condemn capital punishment. Can international members of American medical associations play a leading role in such condemnation? Do medical journals have a role? These issues deserve to be discussed at all levels.

G.A. Fava, Bologna

\section{KARGER \\ Fax +4161306 1234 \\ E-Mail karger@karger.ch} www.karger.com (c) 2000 S. Karger AG, Basel

0033-3190/00/0695-0231\$17.50/0

Accessible online at: www.karger.com/journals/pps
Prof. Giovanni A. Fava

Dipartimento di Psicologia

Università degli Studi di Bologna

Viale Berti Pichat 5

I-40127 Bologna (Italy) 